\title{
Alicja na wygnaniu. Anya v strane chudes Vladimira Nabokova jako przykład adaptacji
}

\section{Olga Letka-Spychała}

Uniwersytet Warmińsko-Mazurski w Olsztynie olga.letka@uwm.edu.pl

\begin{abstract}
Streszczenie
Niniejszy artykut jest poświęcony rosyjskojęzycznemu przekładowi Alicji w Krainie Czarów Lewisa Carrolla wykonanemu przez Vladimira Nabokova w 1923 rokи (Аня в Стране Чудес). Istotnym elementem jego genezy jest fakt, iz tekst sekundarny powstawat w czasie, gdy pisarz, podobnie zreszta jak inni członkowie rosyjskiej inteligencji, przebywał na emigracji. Punktem wyjścia dla rozważań jest potraktowanie Nabokovowskiej wersji jako adaptacji, celem wskazanie w jaki sposób adaptacyjne zabiegi zniekształcity oryginat, na jakie zyski i straty go narazity. Autor skupia się na dwóch elementach tytułowej Krainy Czarów: nazwach bohaterów oraz literackich aluzjach przepuszczonych przez tłumacza przez filtr rosyjskiej kultury. Ich zestawienie $z$ oryginatem ujawniło zmiany $w$ warstwie semantycznej antroponimów $i$ układzie formalnym parodiowanych tekstów. Niemniej jednak, udomowienie przyniosło również zyski w postaci wzbogacenia tekstu o funkcje terapeutyczna pozwalajaca rosyjskim ekspatriantom przetrwać trudy wygnania i zachować pamięć o utworach należacych do rosyjskiego kanonu literackiego.
\end{abstract}

Słowa kluczowe: adaptacja, Anya v strane chudes, język rosyjski, przekład, Vladimir Nabokov

Abstract

Alice in Exile. Anya $v$ strane chudes by Vladimir Nabokov as an Example of Adaptation

This paper explores a Russian translation of Lewis Carroll's Alice's Adventures in Wonderland made by Vladimir Nabokov in 1923. A significant aspect of its emergence relates to the fact that the target text was created when the writer and many other representatives of the Russian intelligentsia were living in exile. The starting point for the article is the hypothesis that Nabokov's version is an adaptation. The aim of the paper is to show how adaptive procedures influence the original and what profits and losses they produce. The author focuses on two elements of the book: the names of the characters and literary allusions both filtered through the Russian culture by the translator. Their juxtaposition with the original reveals changes in the semantic layer of proper names and in the formal structure of parodied texts. Nevertheless, this "domestication" also brings a new value. It enriches the target text with an additional therapeutic function which allowed Russian expatriates and their children to deal with hardships of exile and to keep Russian canonical literary works in their minds. 
Key words: adaptation, Anya $v$ strane chudes, Russian language, translation, Vladimir Nabokov

\section{Wstęp}

Przekład literatury dla dzieci wydaje się być zajęciem nie obarczonym tak wielkim zaangażowaniem i wysiłkiem jak przekład literatury poważnej. O mylności tego stwierdzenia przekonują obszerne studia koncentrujące się głównie na obdarzonym odmiennym zmysłem estetycznym i inną wrażliwością odbiorcy oraz na jego roli w procesie translacji. Riitta Oittinen (1993: 68) sugerowała, by thumacze traktowali niedorosłego czytelnika jak abstrakcyjnego superadresata i zalecała im dotarcie do obrazu dziecka wytworzonego w ramach określonej kultury. Tłumacz, jej zdaniem, powinien zanurzyć się w karniwalistycznym świecie dziecięcym i ponownie go doświadczyć (Albińska 2009: 259-260). Cenną wskazówkę w tej kwestii dała Ewa Zarych (2016: 213) twierdząc, że nie tylko kultura, ale również czasy projektują obraz dziecka. Uwaga ta jest trafna, zwłaszcza gdy przywołamy wydarzenia mające dla danego narodu znaczenie historyczne. W Rosji za takie należy uznać tzw. pierwszą falę emigracji będącą reakcją na polityczne perturbacje związane z klęską białych w wojnie domowej w latach 1917-1922. Wśród emigrantów znaleźli się przedstawiciele wielu dziedzin życia społecznego (pisarze, filozofowie, politycy, inżynierowie), którzy wraz z rodzinami odnajdowali schronienie w Niemczech, Francji, Anglii, Turcji czy Czechach. Uchodźctwo, zawsze noszące piętno tragizmu i ludzkiego dramatu, było szczególnie dotkliwe dla dzieci. Pozbawione możliwości ukończenia krajowych szkół, z dala od przyjaciół i rodzinnego domu, doznawały bolesnego szoku wywołanego zetknięciem z odmienną kulturą, językiem i obcą przestrzenią geograficzną. W niezwykle obrazowy sposób stan ich duszy opisał Vasilij Zenkovskij (2001: 126) przyrównując ją do ,na wpół zniszczonego domu, w którym ocalało tylko kilka pomieszczeń a wszystko pozostałe uległo zburzeniu”. Jednym ze środków zagłuszających tęsknotę za ojczyzną i utrwalających wspomnienie o niej była twórczość literacka, a ściślej literatura pisana z myślą o najmłodszych. Specyficzne warunki, w jakich powstawała nałożyły na nią obowiązek pielęgnowania tego, co jest niezbędne do zapewnienia ciągłości istnienia narodu - tożsamości kulturowej.

Vladimir Nabokov, jako jeden z wielu pisarzy-emigrantów, zmierzył się z tym jakże odpowiedzialnym zadaniem. Uczynił to głównie dzięki tłumaczeniu powieści Lewisa Carrolla Alicja w Krainie Czarów opublikowanemu w 1923 roku w berlińskim wydawnictwie Gamaiun pod pseudonimem V. Sirin. Choć powieść angielskiego matematyka, podobnie zresztą jak w Polsce, doczekała się w Rosji kilkunastu wersji, wariant autora Lolity niezmiennie cieszy się 
szczególnym uznaniem krytyków ${ }^{1}$. Oprócz językowej wirtuozerii, umożliwiającej niezwykle trafne odtworzenie gier językowych i stworzenie właściwej oryginałowi atmosfery nonsensu, na uwagę zasługuje sposób, w jaki Nabokov obszedł się z materiałem kulturowym² ${ }^{2}$ Tłumacz dokonał, co jest zrozumiałe, swoistej re-interpretacji. Przemodelował świat przedstawiony tak, by dziewczynka z kart powieści Carrolla nie czuła się w nim wyobcowana. Nadał jej nowe, egzotyczne imię Ania i obdarzył znajomością języka rosyjskiego. W tym świecie, obowiązującą walutą są kopiejki a nie szylingi/pensy (shillings and pence - 44 копейки), przysmakiem są paszteciki nie tarta (пирожки - tarts), a prawa noga Ani zamieszkuje pod rosyjskim adresem: Miasto Dywanik (Город Коврик), Gubernia Parkietowa (Паректная Губерния). Nie odnajdziemy w nim również faktów nawiązujących do historii Wielkiej Brytanii, a ściślej do zdobycia władzy przez Wilhelma Zdobywcę, późniejszego króla Anglii. Zamiast tego, Mysz opowiada o wielkim księciu Rusi Kijowskiej - Włodzimierzu Monomachu i jego synu Mścisławie, który po śmierci ojca przejął panowanie nad Kijowem ${ }^{3}$ Te przykłady dowodzą, że Kraina Czarów wykreowana przez Nabokova nie jest wiernym odbiciem Krainy Czarów Carrolla, dlatego też w niniejszym artykule podejmiemy próbę prześledzenia innych przesunięć dokonanych w obrębie onomastyki i aluzji literackich. Chcemy udzielić odpowiedzi na następujące pytania: w jaki sposób adaptacja wpłynęła na obrazy bohaterów i ostateczny kształt literackich nawiązań? Co nowego wniosła? Na jakie straty naraziła wskazane elementy?

Nasz wywód rozpoczniemy zatem od przybliżenia istoty kluczowego dla nas pojęcia, jakim jest adaptacja.

\section{Kilka słów o adaptacji}

Węższy, translatologiczny kontekst adaptacji w oczywisty sposób odsyła do najstarszej strategii przekładowej, sięgającej jeszcze czasów starożytnych. Na przestrzeni wieków jej terminologia i status ulegały modyfikacjom, ale niezmiennym pozostawało usytuowanie zawsze w opozycji do alienacji. Friedrich Schleiermacher, który wprowadził do obiegu i zdefiniował owe przeciwstawne strategie pojmował je w kategoriach ,importu” i ,eksportu”

\footnotetext{
${ }^{1}$ Przed Nabokovem przekładu Alicji dokonali: anonimowy autor - Sonya v tsarstve Diva (1879), Matilda Granstrem (1908), Poliksena Sołowjowa (1909), Aleksandra Rozhdestvenskaya (1912), Mikhail Chekhov (1913), D’ Aktil (1923) (Гарциано 2009: 206).

${ }^{2}$ Rosyjskojęzyczny przekład Nabokova doczekał się wielu omówień. Zob.: Warren Weaver (1964), Siemion Karlinsky (1970), Julian Connolly (1995), Stanislav Shvabrin (2007), Natalia Vid (2008), Victor Fet (2009) Svetlana Garziano (2017).

${ }^{3}$ Fragment o Włodzimierzu Monomachu pochodzi z podręcznika o historii Rosji Sergeya Platonova (Fet 2009: 54).
} 
autora. W jego rozumieniu tłumacz opowiadając się za opcją alienacji przybliża czytelnika do autora. Naturalizacja (adaptacja) wyznacza odwrotny kierunek tego transferu. Tym razem to autor „wykonuje ruch w stronę czytelnika” (Schleiermacher [1813] 2006: 49). Tezy niemieckiego filozofa, będącego zwolennikiem thumaczenia wyobcowanego, zostały uznane przez Antoine’a Bermana za główne wykładniki etyki przekładu (Markiewka 2013: 138). Zgodnie z jej naczelnym założeniem tekst tłumaczony winien być takim miejscem, gdzie uobecnia się odmienność kulturowa (Venuti 1995: 20). Myśl Schleiermachera znalazła również swą kontynuację w rozważaniach teoretycznych Lawrence'a Venutiego. W jego przestrzeni badawczej alienacja i adaptacja funkcjonują pod pojęciami oswojenia (domestication) i egzotyzacji (foreignization). Pierwszą opcję badacz utożsamiał z ,etnocentryczną redukcją tekstu źródłowego do wartości języka docelowego" (Venuti 1995: 20), drugą z wiernym odtworzeniem obcych elementów kulturowych i umożliwieniem czytelnikowi dotarcia do innej kultury i jej tekstów. Venuti, podobnie jak inni teoretycy przekładu, był niechętny oswojeniu. Opisywał ją jako etnocentryczną przemoc popełnianą na tekście oryginału i zarzucał wytwarzanie złudnego poczucia autentyczności (Venuti 1995: 21). Adaptacja była również wymieniana przez Jeana Vinaya i Jeana Darbelneta jako jedna z siedmiu strategii przekładowych (Vinay, Darbelnet [1958] 1995: 84-93). W ich pojmowaniu polegała ona na „zastępowaniu faktów języka źródłowego wyrażających fakty nieznane w kulturze języka docelowego przez elementy równoważne funkcjonalnie, czyli sytuacyjnie ekwiwalentne" (Dąmbska-Prokop 2000: 27).

$\mathrm{Na}$ gruncie literatury dziecięcej również pojawiają się rozbieżne opinie co do statusu adaptacji. Tu istotnym pozostaje głos szwedzkiego pedagoga Göte Klingberga uważającego, że adaptacja kontekstowa, czyli powtórne uproszczanie oryginału, jest bezsensowne, gdyż został on już dostosowany do młodego odbiorcy przez samego autora. Jego zdaniem przekład nie powinien być ani łatwiejszy ani trudniejszy, ani mniej ani bardziej interesujący od oryginału. Jedynym zadaniem thumacza jest zachowanie takiego samego stopnia adaptacji co w pierwowzorze (Klingberg 1986: 12-13,18). Inaczej adaptację postrzega Riitta Oittinen, która twierdzi, że „tłumacz jest upoważniony do tworzenia, a nie tylko do odtwarzania” (Oittinen 2000: 21). Rezultatem twórczego procesu jest więc produkt, który należy traktować jako odrębną i autonomiczną kompozycję. Jedną z pozytywnych stron adaptacji jest jej wartość ocalająca. Korzystając z przysługującego mu prawa do własnej interpretacji i dokonywania przekształceń tłumacz wydobywa oryginał z odmętów zapomnienia i daje mu szansę na nowe życie. Zalety adaptacji dostrzegła również Linda Hutheon. Według autorki Teorii adaptacji (A Theory of Adaptation) to, że jest ona tekstem „drugim” wcale nie oznacza, że jest wytworem 
gorszym i drugorzędnym ${ }^{4}$. Wprawdzie deformuje i zniekształca treść oryginału, ale może go również urozmaicać i aktualizować. Hutheon zarysowała szersze pole funkcjonowania tego pojęcia:

Adaptacja jako produkt to zapowiedziana i głęboka transpozycja danego dzieła lub grupy dzieł. Może ona łączyć się ze zmianą medium (klasyczna adaptacja filmowa, ale także np. nowelizacja filmu), zmianą gatunku (np. epika wierszowana przekształcona na prozę), oraz ze zmianą kontekstu czy ramy narracyjnej (np. opowiedzenie tej samej historii z innego punktu widzenia).

Adaptacja jako proces twórczy jest zawsze (re-)interpretacją i (prze-)tworzeniem: w tej perspektywie można ją odczytywać albo jako zawłaszczenie wcześniej istniejącego dzieła, albo jako akt jego ocalenia i utrwalenia.

Adaptacja jako akt percepcji to forma intertekstualności: tekst jest odbierany jako adaptacja, jeśli zostanie odczytany jako palimpset odwołujący się do innych dzieł zapisanych w naszej pamięci kulturowej. (np. film Anna Karenina zostanie odebrany inaczej przez widza, który zna powieść Tołstoja i jej tło historyczno-literackie, a inaczej przez odbiorcę „,naiwnego”, który spodziewa się happy endu).

(Hutheon 2006: 7-8, cyt. za: Woźniak 2012: 23)

Umieszczając przekład Alicji w takim interpretacyjnym szablonie przekonujemy się, że spełnia on wszelkie warunki, by móc zostać nazwanym adaptacją ${ }^{3}$. Po pierwsze, ze względu na to, że Nabokov dokonuje głębokiej transpozycji elementów kulturowych tekstu oryginalnego, która zmienia także semantyczną i metaforyczną „otoczkę” bohaterów. Po drugie, pod względem fabularnym thumacz niewątpliwie wzoruje się na przekazie Carrolla. Zważywszy jednak na emigracyjne tło przekładu i pojawiające się w ślad za tym nowe odczytania historii o Alicji możemy mówić tu nie tyle o zawłaszczeniu dzieła angielskiego autora, co o jego rekontekstualizacji. Po trzecie, parodiując dzieła Aleksandra Puszkina i Michaiła Lermontowa Nabokov wkracza na terytorium rosyjskiej klasyki. Za pomocą humoru reaktywuje konkretne przekazy, odświeża je a nawet przyczynia się do ich zaistnienia w świadomości najmłodszych czytelników.

\section{Jak oswoić Kota z Cheshire?}

Odwołajmy się do pierwszej sytuacji, w której Nabokov udomawia stworzenia zamieszkujące Krainę Czarów. Musimy pamiętać, że w ich przypadku mamy do czynienia z obiektami socjo-

${ }^{4}$ Szerzej o adaptacji zob.: Michał Borodo (2009, 2014), Tomasz Markiewka (2013), Monika Woźniak (2012). 
kulturowymi silnie zakorzenionymi w rzeczywistości językowej. Oznacza to, że thumacz staje przed zadaniem przekazania zarówno sensu (znaczenie głębokie/przenośne), jak i obrazu (znaczenie powierzchniowe/dosłowne) postaci nierzadko wywodzących się z metafor. I o ile na przykład Gąsienica (Гусенийa) czy Orlątko (Орленок) są pozbawione kulturowometaforycznej proweniencji (poza zachowaniem w tłumaczeniu rodzaju męskiego w przypadku pierwszego bohatera), o tyle Kot z Cheshire, Marcowy Zając, Kapelusznik i Fałszywy Żółw już ją posiadają. Śledząc odkształcenia w warstwie znaczeniowej/obrazowej bohaterów w polskojęzycznych przekładach Alicji Jolanta Kozak posłużyła się analizą składnikową tekstu, która również nam pozwoli prześledzić oddziaływanie adaptacji na konkretne semy konstytuujące imiona znaczące.

Przyjrzyjmy się stworzeniu posiadającemu umiejętność teleportacji i pozostawiania po sobie szerokiego uśmiechu, czyli Kotu z Cheshire. Jego nazwa jest realizacją metafory to grin like Cheschire cat, której w języku polskim odpowiada fraza „szczerzyć się jak głupi do sera” (Kozak 2000: 170). W książce The Annotated Alice Martin Gardner wysuwa dwie tezy co do genezy owego porzekadła. Pierwsza, mówiła o szyldach na gospodach w Cheshire (skąd pochodził Carroll) przedstawiających wizerunki szeroko uśmiechniętych lwów. Druga, możliwe źródło pochodzenia upatrywała w serach przypominających swym kształtem kota, z których niegdyś słynęło wspomniane hrabstwo (Gardner 1960: 63). W dialogu pomiędzy Alicją i Księżną widzimy, w jaki sposób obraz kota zostaje wtłoczony w zdekomponowany frazeologizm to grin like Cheshire Cat:

\section{Oryginal}

\footnotetext{
"why your cat grins like that?"

"It's a Cheshire cat," said the Duchess, "and that's why.

"I didn't know that Cheshire cats always grinned; in fact, I didn't know that cats could grin."

"They all can," said the Duchess; "and most of 'em do."

"I don't know of any that do," Alice said very politely, feeling quite pleased to have got into a conversation.

"You don't know much," said the Duchess; "and that's a fact."
}

(Carroll 1998: 82-83)

W przekładzie rosyjskiego emigranta Cheshire Cat zostaje zastąpiony Maslenicznym Kotem: 


\section{Przekład}

Почему это ваш кот ухмыляется так?

- Это - Масленичный Кот, -отвечала Герцогиня, - вот почему. Хрюшка!

- Я не знала, что такие коты постоянно ухмыляются. Впрочем, я вообще не знала, что коты могут это делать.

- Не всегда коту масленица, - ответила Герцогиня. - Моему же коту - всегда. Вот он и ухмыляется.

- Я этого никогда не знала, - вежливо сказала Аня. Ей было приятно, что завязался умный разговор.

- Ты очень мало что знаешь, - отрезала Герцогиня. - Это ясно.

(Кэрролл 1989: 95-96)

Jeśli odwołalibyśmy się do metody zaproponowanej przez Jolantę Kozak, to schemat semantycznych przesunięć wyglądałby następująco:

semem: Cheshire Cat

1. [+ kot] 2. [+ z Cheshire] 3. [+ fragmentaryczność (sama głowa)] 4. [+uśmiech] 5. [+ szyderstwo 6. [+ wyjaśnienie intertekstualne (odniesienie do popularnego porzekadła)] (Kozak 2000: 175-176).

semem: Masleniczny Kot (Масленичный Kom)

2. $[+$ kot $] 2 .[-] 3 .[-] 4 .[+] 5[-] 6 .[+]$

Nabokov odrzuca oryginalną motywację nazwy bohatera i porusza się po obszarach dobrze znanych rodzimemu odbiorcy. W konsekwencji pomija obco brzmiący toponim Cheshire i zastępuje go określeniem Масленичный wplątując go tym samym w kontekst Maslenicy hucznego święta przypadającego siedem dni przed Wielkanocą. Strategia konstruowania tej postaci ukierunkowana na maksymalne przybliżenie jej rosyjskiemu czytelnikowi nie ograniczyła się tylko do zamiany pojedynczego semu. Potwierdza to użycie w wypowiedzi Księżnej przysłowia: Не всегда коту масленица (nie zawsze jest się posiadaczem dobrej passy) i jego parafrazy Моему же коту - всегда, która nie tylko przypieczętowuje jego „świąteczny rodowód”, ale równocześnie jest substytutem anglojęzycznego porzekadła to grin like Cheshire Cat. Masleniczny Kot w wersji Nabokova staje się więc nie tyle posiadaczem 
szerokiego uśmiechu co dobrej passy, która, jak możemy się domyślać, go wywołuje. Jego językowym sygnałem u Nabokova jest czasownik yхмылятьься nie wchodzący, tak jak czasownik to grin, w zakres intertekstualnego odniesienia. Podobnie zresztą dzieje się z fragmentarycznością Kota, która uobecnia się tylko na poziomie tekstowym.

Innym przykładem onimów uwikłanych w idiomatyczno-metaforyczne zależności są Marcowy Zając (March Hare) oraz Kapelusznik (Hatter) - uczestnicy absurdalnej herbatki. Obu łączy szaleństwo będące ważnym semantycznym ogniwem występujących w anglojęzycznej kulturze porównań: Mad as a March Hare i Mad as a Hatter. Pochodzenie pierwszego z nich nawiązuje do charakterystycznego zachowania zajęcy w okresie godowym przypadającym w marcu. Drugi odzwierciedla stereotyp o obłąkaniu kapeluszników, którzy przez długotrwałą pracę w oparach rtęci cierpieli na poważne uszkodzenia systemu nerwowego objawiające się halucynacjami (Gardner 1960: 234). O przypadłości intelektualnej Zająca i Kapelusznika Nabokov informuje w tytule rozdziału - Сумашедшие пьют чай (Szaleni piją herbatę), podczas gdy w oryginale szaloną jest popołudniowa herbatka (Mad-Tea Party). Odtworzenie i zestawienie ciągu semów ujawnia ubytki w znaczeniu głębokim:

semem: March Hare

1. [+zając] 2. [+marzec] 3. [+szaleństwo] 4. [+odniesienie intertekstualne, porzekadło Mad as a March Hare]. (Kozak 2000: 177)

semem: Мартовский Заяи (Marcowy Zając)

2. [+zając] 2. [+marzec] 3. [-szaleństwo] 4. [-odniesienie intertekstualne, porzekadło Mad as a March Hare]

sem: Hatter

1. [+kapelusznik] 2. [-szaleństwo] 4. [- odniesienie intertekstualne, porzekadło Mad as a Hatter]

sem: Шляпник (Kapelusznik)

1. [+kapelusznik] 2. [-szaleństwo] 4. [- odniesienie intertekstualne, porzekadło Mad as a Hatter]

W obu przypadkach Nabokov skłania się ku przekładowi literalnemu, który unicestwia konotacje kulturowe i tym samym zubaża „aluzyjność” nazw obu bohaterów. Wprawdzie mógł 
on, podobnie jak w przypadku Maslenicznego Kota, po swojemu zmetaforyzować zająca i kapelusznika, jednakże nie zdecydował się na takie rozwiązanie ze względu na możliwość pojawienia się u rosyjskich czytelników odmiennych konotacji. Obecne w języku rosyjskim frazeologizmy, których spoiwem jest zając, portretują go raczej jako zwierzę tchórzliwe i bojaźliwe ${ }^{5}$. Wykorzystanie tej opcji przenosiłoby punkt kulturowej ciężkości ze stanu psychicznego obłąkania na konkretną wadę. Jeśli chodzi o kapelusznika to repertuar wyrażeń idiomatycznych jakimi mógł posłużyć się thumacz jest ograniczony. Nie odnotowujemy bowiem wyrażeń, z którymi ta postać mogłaby wejść w metaforyczne koligacje. Adaptacja w tym przypadku upraszcza i spłyca poziom znaczeń głębokich obu postaci, wypycha je poza nawias kulturowy i pozostawia w obszarze dosłowności.

Mock Turtle to kolejna postać obdarzona ogromnym metaforyczno-kulturowym potencjałem. Wskazuje na to Gardner objaśniając, iż jest ona pochodną cieszącej się w Anglii popularnością „fałszywej zupy żółwiowej” (Mock Turtle Soup), której głównym składnikiem decydującym o tak charakterystycznej nazwie była cielęca głowa (Gardner 1960: 249). Te „gastronomiczne koneksje” zostały zaakcentowane w rozmowie Królowej Kier z Alicją:

\section{Oryginal}

Have you seen the Mock Turtle yet?"

"No," said Alice. "I don’t even know what a Mock Turtle is."

"It's the thing Mock Turtle Soup is made from," said the Queen.

"I never saw one, or heard of one," said Alice.

"Come on, then," said the Queen, "and he shall tell you his history."

(Carroll 1998: 137)

Inaczej ta relacja wygląda u Nabokova:

\section{Przekład}

- Ты еще не была у Чепупахи?

- Нет, - ответила Аня. - Я даже не знаю, что это.

- Это то существо, из которого варится поддельный черепаховый суп, - объяснила Королева.

${ }^{5}$ Przykłady związków frazeologicznych z leksemem zając (заяц): Заяц самого себя боится (Zając boi się samego siebie); Блудлив как кот, труслив как заяц; Жаден, как волк, а труслив, как заяи (Chciwy jak wilk, tchórzliwy jak zając); Вор что заяц: и тени своей боится (Złodziej jest jak zając - boi się swego cienia). [Por.: http://wordsland.ru/zs/dolina/index.php?s=20. Data ostatniego dostępu: 20.03.2020]. 
- В первый раз слышу! - воскликнула Аня.

- Так пойдем, - сказала Королева. - Чепупаха расскажет тебе свою повесть

(Кэрролл 1989: 154-155)

Dla rosyjskiego czytelnika, niezbyt dobrze orientującego się w zwyczajach kulinarnych Anglików, powiązanie obrazu bohatera z pozaliterackim kontekstem fałszywej zupy żółwiowej nie jest oczywiste. Choć w wyjaśnieniu Królowej Kier czym jest przedziwne stworzenie pada nazwa tej potrawy - поддельный черепаховый суn, to w przekładzie funkcjonuje ona jakby w oderwaniu od rzeczywistości językowej, z jakiej się wywodzi i od postaci, którą w istocie identyfikuje. Dzieje się tak, ponieważ Nabokov nie korzysta, tak jak uczynił to Carroll, z możliwości zapożyczenia imienia dla tej postaci od przysmaku. Co ciekawe, nie definiuje jej nawet jako żółwia. Ilustrują to poniższe odwzorowania:

semem: Mock Turtle

1. [+żółw] 2. [+pozorny, udawany] 3. [+ nawiązanie do kontekstu kulturowego - zupy Mock Turtle soup]

sem: Yenynaxa

1. [-żółw] 2. [-pozorny, udawany] 3. [- nawiązanie do kontekstu kulturowego - zupy Mock Turtle soup]

Nabokov nie prowadzi czytelnika po zakamarkach obcej kultury, zamiast tego proponuje mu zabawę ze słowami череnaxa (żółw) и чеnyxa (bzdura, nonsens). Stworzona przez niego słowotwórcza innowacja tylko dzięki brzmieniowemu podobieństwu do wyrazu чepenaxa rodzi skojarzenia właśnie $\mathrm{z}$ tym gadem. Ponadto zawiera w sobie semantyczny naddatek $\mathrm{w}$ postaci nowego atrybutu: z fałszywego, żółw staje nonsensownym. Odmienna waloryzacja bohatera ma swe konsekwencje w postaci zmiany jego kontekstowego usytuowania i stanowi również sygnał gatunkowej nieokreśloności. W oryginale przecież nie odnajdujemy wzmianki o wyglądzie stworzenia; wiemy jedynie, iż przyrządza się z niego wspomnianą zupę. Ten brak rekompensuje ilustracja autorstwa Johna Tenniela prezentująca osobnika o korpusie żółwia, cielęcej głowie i dużych oczach. Prawdopodobnie Nabokov zasugerował się nią podczas tłumaczenia epizodu, w którym dochodzi do pierwszego spotkania Ani z nietypowym zwierzęciem: 


\section{Oryginal}

So they went up to the Mock Turtle, who looked at them with large eyes full of tears, but said nothing.

(Carroll 1998: 140)

\section{Przeklad}

Они подошли к Чепупахе, которая посмотрела на них большими телячьими глазами, полными слез, но не проронила ни слова.

(Кэрролл 1989: 157)

W oryginale żółw patrzy na dziewczynkę dużymi oczami pełnymi łez, co oddaje właściwe mu melancholijność oraz przygnębienie. Nabokov nieznacznie rozwija ten opis i wzbogaca go o przymiotnik „,cielęce” pojawiający się w kontekście oczu bohatera (телячьи глаза). Z jednej strony jest to oczywiste nawiązanie i do fałszywej zupy i do obrazka Tenniela. Z drugiej, przenośne znaczenie tego epitetu (oczy o sennym i bezmyślnym wyrazie) koresponduje z semantyczną zawartością leksemu yenyxa wchodzącego w strukturę onimu Yenynaxa.

\section{Parodie Vladimira Nabokova}

Oprócz imion znaczących adaptację obserwujemy również w warstwie literackich nawiązań. Tekst Carrolla obfituje we fragmenty będące parodiami utworów o silnym zabarwieniu dydaktycznym, niezwykle popularnymi w okresie wiktoriańskim. Cechą charakterystyczną rosyjskojęzycznego utworu jest to, że Nabokov nie sili się na ich ekwiwalentny przekład. Podąża co prawda śladami angielskiego pisarza, ale materiałem translatorskiego przetworzenia czyni nie teksty, w których wybrzmiewa moralizatorski ton, a utwory dziewiętnastowiecznych klasyków: Aleksandra Puszkina i Michaiła Lermontowa. Znajdziemy tu wyraźne aluzje do Pieśni o wieszczym Olegu (1822), i do poematu Cyganie (1824) Puszkina, i do wiersza Borodino (1837) i do Kozackiej kotysanki (1840) Lermontowa. W porównaniu ze wzorcami literackimi wykorzystanymi przez Carrolla, teksty parodiowane przez Nabokova cechują się odmienną wymową ideową, innym rejestrem, problematyką i przesłaniem. Nie przeszkodziło mu to jednak w stworzeniu ,kolaży” zespalających zarówno elementy macierzyste i te spoza rodzimego kanonu literackiego. Nabokov zdawał sobie sprawę, że rosyjscy ekspatrianci są bardzo dobrze obeznani z tekstami Puszkina i Lermontowa. Wykorzystał tę wiedzę i nadał im nową, terapeutyczną funkcję. Powrót do dzieł klasyków minimalizował bolesne uczucie 
osamotnienia i ofiarował namiastkę utraconej ojczyzny. Służył również ich utrwaleniu w świadomości dzieci wyrwanych ze swego kulturowego otoczenia. Nabokov umiejętnie sparafrazował i przetransformował pierwowzory, dbając $z$ jednej strony o zachowanie struktury formalnej (identyczna liczba sylab, układ wersyfikacyjny, miara wierszowa) każdego z nich, z drugiej - o stworzenie właściwego Carrollowi parodystycznego efektu.

Ze względu na oczywiste ograniczenia rezygnujemy ze szczegółowego omówienia każdego z wykorzystanych przez tłumacza tekstu. Skupimy się na trzech, które w najbardziej obrazowy sposób przedstawiają mechanizm działania adaptacji. W utworze Carrolla Alicja niejednokrotnie staje przed zadaniem zadeklamowania wierszy. Czynność ta za każdym razem sprawiała dziewczynce trudność, ponieważ z jej ust wydobywały się przeinaczone wersy. W drugim rozdziale, gdy Alicja stara się wyrecytować utwór Isaaca Watsa How Doth the Little Busy Bee, w jego miejsce wybrzmiewają słowa: How Doth the Little Crocodile:

How doth the little crocodile

Improve his shining tail,

And pour the waters of the Nile

On every golden scale!

How cheerfully he seems to grin,

How neatly spreads his claws,

And welcome little fishes in

With gently smiling jaws!

(Carroll 1998: 20)

U Nabokova swego rodzaju matrycą stają się słowa piosenki Птичка божия не знает pochodzące $\mathrm{z}$ utworu Cyganie Puszkina. Bohaterem poematu jest ptak (птичка) symbolizujący wolność i jednocześnie stanowiący alegorię Cyganki Zemfiry - obiektu głębokich uczuć Aleko. W przypływie zazdrości protagonista zabija swą ukochaną, co jest odbierane jako przejaw jego słabości. Nabokov, co jest zrozumiałe, nie zdecydował się ani na odtworzenie tragicznej historii ani na wykorzystanie motywu ptaka. Posiłkuje się pomysłem Carrolla i zastępuje go niesfornym krokodylem nieznającym ,ni trosk ni trudu”:

Крокодилушка не знает

Ни забот и ни труда.

Золотит его чешуйки

Быстротечная вода. 
Милых рыбок ждет он в гости,

На брюшке средь камышей:

Лапки врозь, дугою хвостик,

И улыбка до ушей...

(Кэрролл 1989: 27)

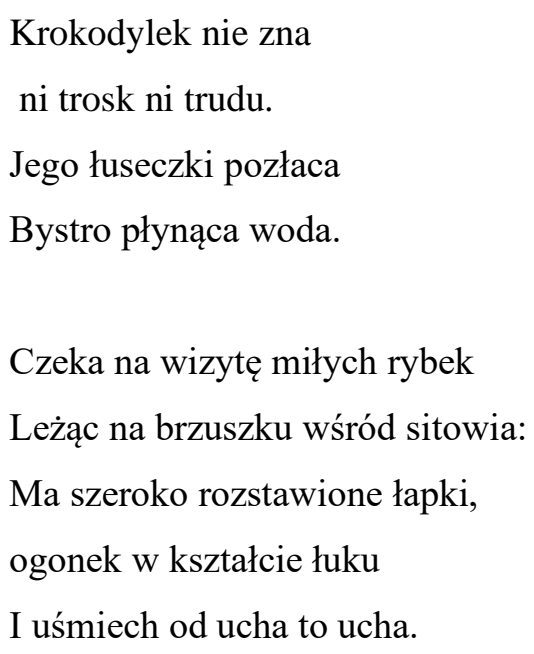

(Przekład filologiczny)

Ta $\mathrm{w}$ istocie przerażająca opowieść o podstępnym drapieżniku czyhającym na swe ofiary została opowiedziana przez autora Lolity językiem dziecka. Jest to mowa zinfantylizowana obfitująca w zdrobnienia (крокодилушка, чешуйки, лапки, хвостик), dzięki czemu niebezpieczny i okrutny gad zyskuje łagodne i przyjazne oblicze. Bohater nie wzbudza więc strachu a staje się źródłem pozytywnych skojarzeń: dziecko wizualizuje szeroko uśmiechniętego krokodylka zapraszającego małe rybki w gości; leży on sobie na brzuszku, jego łapki są szeroko rozstawione a ogonek ułożył się na kształt łuku. Tłumaczowi udaje się odtworzyć zawartość pierwowzoru, pomimo wprowadzenia kilku modyfikacji np. pominięcie fragmentu o rzece Nil i zastąpienie tego elementu hiperonimem - bystro płynącą wodą oraz zastosowania się do formalnych ograniczeń narzuconych przez adaptowany tekst Puszkina. Humorystyczne zabarwienie wzmacnia natomiast charakterystyczna konfrontacja patosu i trywialności odtwarzanej sytuacji lirycznej (Connolly 1995: 20-21).

Taki sposób obchodzenia się z zarówno z oryginałem, jak i tekstem adaptowanym nie należy do odosobnionych. W rozdziale szóstym pojawia się epizod, w którym Księżna kołysze swego syna w takt kołysanki będącej parodią sentymentalnego utworu Davida Batesa Speak Gently. Poeta prosi w nim, by rodzice rozmawiając z dziećmi używali łagodnego tonu i aby kierowali się miłością. Carroll, doskonale orientujący się w trudnej sytuacji dzieci w Anglii, 
wykorzystuje swą wiedzę i tworzy wersję wiersza odpowiadającą a-symetrycznej, „odwróconej” naturze Krainy Czarów. Na opak interpretuje radę Batesa i przewrotnie zachęca, by mówić do dziecka ostro i wymierzać mu kary cielesne (Speak Roughly):

Speak roughly to your little boy,

And beat him when he sneezes:

He only does it to annoy,

Because he knows it teases.'

CHORUS.

(In which the cook and the baby joined):--

Wow! wow! wow!'

'I speak severely to my boy,

I beat him when he sneezes;

For he can thoroughly enjoy

The pepper when he pleases!'

CHORUS.

'Wow! wow! wow!'

(Carroll 1998: 86)

Nabokov jako oprawę dla swej parodii wybiera Kozacka kołysankę Lermontowa, mającą formę pieśni odśpiewywanej przez matkę nad kołyską niemowlęcia. Piastunka tematyzuje w niej wojenną rzeczywistość mówi o złym Czeczenie czającym się na brzegu i ostrzącym swój kindżał. Poprzez kołysankę wpaja dziecku takie wartości i wzorce postępowań, które w przyszłości uczynią zeń nieustraszonego i niezłomnego wojownika o wolność. Nabokov z premedytacją rujnuje ten podniosły obraz i od pierwszego wersu unieważnia Lermontowowski patos i powagę:

Вой, младенец мой прекрасный,

А чихнешь - побью!

Ты нарочно - это ясно...

Баюшки-баю.

Ay! Ay! Ay! Ay!

То ты синий, то ты красный,

Бью и снова бью!

Перец любишь ты ужасно.

Баюшки-баю.

Xop 
Ay! Ay! Ay! Ay! Ay! Ay!

(Кэрролл 1989: 98)

Wyj dziecino ma przepiękna

Jeśli kichniesz - to pobiję

Robisz to specjalnie - jasna to sprawa

Baju baj.

$\mathrm{Au}$ ! $\mathrm{Au} ! \mathrm{Au} ! \mathrm{Au}$ !

Raz jesteś niebieski, raz czerwony

Biję i biję cię wciąż!

Pieprz lubisz ty okropnie

Baju baj.

CHÓR

$\mathrm{Au} ! \mathrm{Au} ! \mathrm{Au} ! \mathrm{Au} ! \mathrm{Au} ! \mathrm{Au}$ !

(Przekład filologiczny)

Próżno tu również szukać wymownej sugestii Спи младенец мой прекрасньй (Śpij dziecino ma przepiękna), ponieważ w jej miejsce pojawia się groźnie brzmiący imperatyw Boŭ, младенеи мой прекрасный (Wyj dziecino ma przepiękna) nakazujący mu dla odmiany wyć. Przeinaczenie intencji kołysanki, mającej przecież w swym tradycyjnym zamyśle pomóc dziecku w uśnięciu, stanowi źródło humorystycznych doznań. Treść „kołysankowego bajania” wypełnia grożenie karą za umyślne kichanie wywoływane przez zabawy z pieprzem, co w zestawieniu z sytuacją liryczną opisaną przez Lermontowa wprowadza dysonans. Nabokov tradycyjnie nie przekracza granic wyznaczonych przez poetycką konstrukcję tekstu adaptowanego i nie rezygnuje z obecności elementów językowych określających poetykę Lermontowowskiej kołysanki. W przekładzie możemy odnotować symptomatyczne powtórzenie Баюшки-баю i piosenkową refreniczność imitujące płynne i spokojne kołysanie. Ponadto tłumacz zachowuje formę monologu, pomimo tego, iż u Carrolla występuje wyraźny podział sekwencji pomiędzy moralizatorem pouczającym opiekunów (w pierwszej zwrotce) a rodzicem opisującymi swe postępowanie z dziećmi (w drugiej zwrotce).

Innym przykładem takiej re-narracji jest Pieśń o wieszczym Olegu (Песнь о вещем Олеге 1822) Puszkina przeniesiona w świat Homarowego Kadryla w rozdziale dziesiątym. Inspiracją dla tego utworu posłużył latopis przedstawiający historię księcia Olega i przepowiedni o tym, że zginie przygnieciony przez swego ukochanego konia. W oryginale Alicja zostaje poproszona przez Gryfa o wyrecytowanie wiersza Isaaca Watsa The Sluggar piętnującego 
lenistwo i brak ambicji wśród dzieci. Dziewczynka nie mogąc wyzwolić się spod wpływu tańca niczym w transie wypowiada frazy, które w niczym nie przypominają dobrze znanego wiersza:

"'Tis the voice of the Lobster; I heard him declare,

'You have baked me too brown, I must sugar my hair.'

As a duck with its eyelids, so he with his nose

Trims his belt and his buttons, and turns out his toes."

When the sands are all dry, he is gay as a lark,

And will talk in contemptuous tones of the Shark,

But, when the tide rises and sharks are around,

His voice has a timid and tremulous sound

(Carroll 1998: 157)

Pomimo, że Carrollowska opowieść o homarze zostaje przekazana z przymrużeniem oka to nie traci waloru dydaktycznego. Autor demaskuje w niej prawdziwą naturę skorupiaka, którego odwaga i śmiałość są tylko grą pozorów. Humorystyczny akcent tej nieskomplikowanej historii wzmacniają zabawy z jego głosem. Pewność siebie zostaje zwerbalizowana poprzez czasownik to declare (ogłosić coś publicznie) sugerujący stanowczość i zdecydowanie mówcy. Homar czując się bezpiecznie na lądzie pozwala sobie na pogardliwy ton wobec zagrażającego mu rekina (will talk in contemptuous tones of the Shark). Gdy jednak sytuacja się zmienia i na horyzoncie pojawia się drapieżnik jego głos zmienia się w przestraszony i drżący (His voice has a timid and tremulous sound).

Nabokov portretuje homara w nieco odmienny sposób, ale krytykuje te same przywary:

Как дыня, вздувается вещий Омар:

„Меня, - говорит он, - ты бросила в жар;

Ты кудри мои вырываешь и ешь,

Осыплю я перцем багровую плешь".

Омар! Ты порою смеешься, как еж,

Акулу акулькой с презреньем зовешь;

Когда же и вправду завидишь акул,

Ложишься ничком под коралловый стул!

(Кэрролл 1989: 175) 
Jak melon nadyma się wieszczy Homar

„Wrzuciłaś mnie do wrzątku - powiada

Ty pukle me wyrywasz i jesz

Posypię pieprzem purpurową łysinę".

Homarze! Czasem śmiejesz się jak jeż

Rekina rekinkiem z pogardą zwiesz

Kiedy naprawdę zobaczysz rekiny,

Chowasz się pod muszlą perłowca!

(Przekład filologiczny)

Pyszałkowatość skorupiaka zostaje podniesiona do potęgi dzięki porównaniu „nadymać się jak melon" parafrazującemu pierwszy wers ballady Puszkina: Как ныне сбирается вещий Олег. Nabokov zapożycza schemat fabularny od Carrolla, ale w opisie zachowania homara jest bardziej szczegółowy. Skorupiak śmieje się jak jeż, a swój lekceważący stosunek do rekina demonstruje poprzez nazywanie go rekinkiem. Tłumacz inaczej charakteryzuje również reakcję zwierzęcia, gdy ten dostrzega wroga. Homar nie ścisza głosu tylko kurczy się i chowa pod muszlą perłowca. Nie tylko ukazanie podwójnego oblicza homara staje się tu źródłem komizmu. Nabokov dopełnia je poprzez zestawienie lakonicznej i banalnej w swej treści opowiastki z monumentalną formułą ballady Puszkina oraz skarykaturowanego wieszczego Homara z zasłużonym władcą Olegiem.

\section{Wnioski}

Niniejszy artykuł został poświęcony rosyjskojęzycznemu tłumaczeniu Alicji w Krainie Czarów wykonanemu przez Vladimira Nabokova w 1923 roku. Przekład ten, odnosząc się do perspektywy interpretacyjnej Lindy Hutheon, potraktowaliśmy jak adaptację. Uzasadniliśmy ją nie tyle specyfiką samego tekstu (literatura dziecięca) i jego odbiorcy, co szczególną atmosferą czasów w jakich przekaz powstawał. Przypomnijmy, że był to okres, gdy Nabokov i większość jego rodaków znaleźli się poza granicami Rosji. Historyczne uwarunkowania wpłynęły na to, że opowieść o dziewczynce, która znalazła się z dala od swej rodziny w obcej krainie, zyskała wśród małych emigrantów i ich rodziców zupełnie nowy sens.

By unaocznić zamiar Nabokova, polegający na wyeliminowaniu czynnika obcego, w polu naszych obserwacji umieściliśmy nazwy mówiące oraz parodie wiktoriańskich wierszy. Chcieliśmy ustalić, jaki zyskały kształt w przekładzie po poddaniu ich zabiegom adaptacyjnym. W przypadku pierwszej grupy posłużyliśmy się analizą składnikową tekstu, 
pozwalającą zaobserwować istotne zmiany w zarówno w obrębie znaczeń powierzchniowych, jak i głębokich. Carroll konstytuuje onimy w oparciu o związki frazeologiczne odzwierciedlające fakty właściwe tylko kulturze angielskiej. Ich wierne oddanie jest zatem uzależnione od stopnia metaforycznego nasycenia danego antroponimu oraz możliwości odnalezienia takiego odpowiednika, który nie zaburzałby zamysłu Carrolla. Nabokov przy udomawiania nazw własnych nie ogranicza się tylko do jednej techniki. W przypadku Kota z Cheshire stosuje kulturowy ekwiwalent, jakim jest Masleniczny Kot. Sposób portretowania tej postaci, przypomina pierwowzór. Opiera się bowiem na porzekadle Не всегда коту Масленица, które nadaje mu odmienną etiologię i powoduje straty w odtworzeniu takich atrybutów jak fragmentaryczność czy szeroki uśmiech. Udosłownienie Kapelusznika i Marcowego Zająca doprowadza z kolei do całkowitego pozbawienia ich kulturowego nacechowania. O tak poważnej ingerencji w warstwę znaczeń głębokich zadecydowały ukształtowane w świadomości najmłodszych wyobrażenia zbyt mocno odbiegające od prototypu. Ciekawym przypadkiem adaptacyjnych posunięć jest Fałszywy Żółw, który zyskuje miano bliżej nieokreślonej Чеnynaxu. W przekładzie Nabokova temu bohaterowi odebrano nie tylko kulinarny rodowód, ale również sposobność bycia fałszywym.

Aluzje literackie - to grupa, która inaczej zareagowała na adaptacyjne eksperymenty tłumacza. Tu, literackim tworzywem rekonfiguracji stały się dobrze znane emigracyjnemu audytorium przekazy Puszkina i Lermontowa. Jednakże Nabokov nie eksploatuje schematu fabularnego ani Pieśni o wieszczym Olegu, ani Kozackiej kotysanki a zwraca się ku wątkom narzuconym przez Carrolla. Nie oznacza to, że tłumacz podporządkowuje się ustalonym przez angielskiego autora kompozycyjnym regułom. Autor Lolity umiejętnie wkomponowuje historie i postaci w literackie szablony zapożyczone od klasyków. Podobnie jak Carroll prowadzi intertekstualną grę z tradycją literacką przesuwając tym samym granicę pomiędzy dyskursami i konwencjami.

\section{Bibliografia}

Albińska, Karolina (2009) „"Tylko to, co najlepsze jest dość dobre dla dzieci", czyli o dylematach tłumacza literatury dziecięcej”. [W:] Przekładaniec. Pótrocznik Katedry UNESCO do Badań nad Przekładem i Komunikacja Międzykulturowa UJ, 22-23; 259282. 
Borodo, Michał (2009) „Adaptacje w dobie globalizacji”. [W:] Przekładaniec. Pótrocznik Katedry UNESCO do Badań nad Przekładem i Komunikacją Międzykulturową UJ, 22-23; 205-219.

Borodo, Michał (2014) „Przekład, adaptacja i granice wyobraźni”. [W:] Przekładaniec. Pótrocznik Katedry UNESCO do Badań nad Przekładem i Komunikacją Międzykulturowa UJ, 28; 179-194.

Carroll, Lewis (1998) Alice's Adventures in Wonderland. Chicago, IL: Volume One Publishing.

Connolly, Julian (1995) „Ania v strane chudes”. [W:] Vladimir E. Alexandrov (red.) The Garland Companion to Vladimir Nabokov. New York: Garland; 18-25.

Dąmbska-Prokop, Urszula (2000) Mała encyklopedia przekładoznawstwa. Częstochowa: Wydawnictwo Wyższej Szkoły Języków Obcych i Ekonomii.

Fet, Victor (2009) „Beheading First: on Nabokov's Translation of Lewis Caroll”. The Nabokovian 63; 52-63.

Gardner, Martin (1960) The Annotated Alice: Alice's Adventures in Wonderland \& Through the Looking Glass. New York: C.N. Potter.

Гарциано, Светлана [Garziano Svetlana] (2017) „«Мы с Временем рассорились в прошлом Мартобре...»: лингвистические и культурологические анахронизмы в переводе В.В. Набокова «Аня в стране чудес» (1923)”. [W:] Детские чтения 12; 206-226.

Hutheon. Linda (2006) A Theory of Adaptation. New York: Routledge.

Karlinsky, Simon (1970) „Anya in Wonderland: Nabokov's Russified Lewis Carroll”. [W:] Alfred Appel, Jr., Charles Newman (red.) Nabokov. Criticism, Reminiscences, Translations and Tributes. New York: Northwestern University Press; 310-315.

Klingberg, Göte (1986) Children's Fiction in the Hands of the Translators. Lund: CKW Gleerup.

Кэрролл, Льюис [Carroll Lewis] (1989) Аня в стране чудес [Alice's Adventures in Wonderland]. Владимир Набоков (tłum.). Ленинград: Детская литература.

Kozak, Jolanta (2000) „Alicja pod podszewką języka”. [W:] Teksty Drugie 5; 167-178.

Markiewka, Tomasz (2013) „Herezja adaptacji. Przekład a etyka różnicy”. [W:] Świat i Słowo $1(20) ; 131-143$.

Oittinen, Riitta (1993) I am Me - I am the Other: On the Dialogics of Translating for Children. Tampere: University of Tampere.

Oittinen, Riitta (2000) Translating for Children. Londyn, Nowy Jork: Garland Publishing. 
Schleiermacher, Friedrich ([1813] 2006) „On the Different Methods of Translating”. [W:] Lawrence Venuti (red.) The Translation Studies Reader. London, New York: Routledge; $44-63$.

Shvabrin, Stanislav (2007) Vladimir Nabokov as Translator: The Multilingual Works of the Russian Period. Los Angeles: University of California Press.

Weaver, Warren (1964) Alice in Many Tongues: The Translations of Alice in Wonderland. Wiscolin: Madison UP.

Wordsland.ru. [pobrane $\mathrm{z}$ http://wordsland.ru/zs/dolina/index.php?s=20. Data ostatniego dostępu: 20.03.2020].

Woźniak, Monika (2012) „Adaptacja w przekładach dla dzieci - gawęda terminologiczna”. [W:] Filoteknos 3; 23-36.

Venuti, Lawrence (1995) The Translator's Invisibility. The History of Translation. Londyn: Routledge.

Vid Natalia (2008) „Domesticated Translation: The Case of Nabokov's Translation of Alice's Adventures in Wonderland". [W:] Nabokov Online Journal 2; 1-24.

Vinay Jean-Paul, Jean Darbelnet ([1958] 1995) „A Methodology for Translation.” [W:] Lawrence Venuti (red.) The Translation Studies Reader. London, New York: Routledge; 84-93.

Zarych, Elżbieta (2016) „Przekład literatury dla dzieci i młodzieży - między tekstem a oczekiwaniami wydawcy i czytelnika”. [W:] Teksty Drugie 1; 206-227.

Зеньковский, Василий [Zenkovskij Vasilij] ([1925] 2001) „Детская душа в наши дни”. [W:] Василий Зеньковский (red.) Дети эмиграџии: воспоминания. Москва: Аграф. 